\title{
Future trends in paleoseismology: Integrated study of the seismic landscape as a vital tool in seismic hazard analyses
}

\author{
Alessandro Maria Michetti ${ }^{a, *}$, Franck A. Audemard M. ${ }^{b}$, Shmuel Marco ${ }^{c}$ \\ ${ }^{a}$ Università dell'Insubria, Dipartimento di Scienze Chimiche e Ambientali, Via Valleggio 11, 22100, Como, Italy \\ ${ }^{\mathrm{b}}$ Venezuelan Foundation for Seismological Research-FUNVISIS-, Earth Sciences Department, Caracas, Venezuela \\ ${ }^{\mathrm{c}}$ Department of Geophysics and Planetary Sciences, Tel Aviv University, Tel Aviv 69978, Israel
}

Received 30 March 2004; accepted 31 May 2005

Available online 7 October 2005

\begin{abstract}
This paper forms the Introduction to this Special Issue of Tectonophysics, devoted to selected scientific research presented during events sponsored by the INQUA Subcommission on Paleoseismicity in the past few years. In this note, we summarize the contents of the contributed papers and use the issues they raise to review the state-of-the-art in paleoseismology from a Quaternary geology perspective. In our opinion, the evolution of paleoseismological studies in the past decade clearly demonstrates that in order to properly understand the seismic potential of a region, and to assess the associated hazards, broad-based/multidisciplinary studies are necessary to take full advantage from the geological evidence of past earthquakes. A major challenge in future paleoseismic research is to build detailed empirical relations between various categories of coseismic effects in the natural environment and earthquake magnitude/intensity. These relations should be compiled in a way that is fully representative of the wide variety of natural environments on Earth, in terms of climatic settings, Quaternary tectonic evolution, rheological parameters of the seismogenic crust, and stress environment. For instance, available data indicate that between earthquake magnitude and surface faulting parameters different scaling laws exist, and they are a function of the local geodynamic setting (including style of faulting, typical focal depths, heat flow). In this regard, we discuss in some detail the concept of seismic landscape, which provides the necessary background for developing paleoseismological research strategies. The large amount of paleoseismological data collected in recent years shows that each earthquake source creates a signature on the geology and the geomorphology of an area that is unequivocally related with the order of magnitude of its earthquake potential. This signature is defined as the seismic landscape of the area (e.g., Serva, L., Vittori, E., Ferreli, L., Michetti, A.M., 1997. Geology and seismic hazard. In: Grellet, B., Mohammadioun, B., Hays, W. (Eds.), Proceedings of the Second France-United States Workshop on Earthquake Hazard Assessment in Intraplate Regions: Central and Eastern United States and Western Europe, October 16, 1995, Nice, France, 20-24, Ouest Editions, Nantes, France; Michetti, A.M., Hancock, P.L., 1997. Paleoseismology: understanding past earthquakes using quaternary geology.
\end{abstract}

\footnotetext{
* Corresponding author. Tel.: +39 31326215; secr: +39 313261; fax: +39 31326230.

E-mail addresses: michetti@fis.unico.it (A.M. Michetti), faudemard@funvisis.org.ve (F.A. Audemard M.).
} 
Journal of Geodynamics $24(1-4), 3-10)$. We then illustrate how this relatively new framework is helpful in understanding the seismic behavior of faults capable of producing surface faulting and provides a comprehensive approach for the use of paleoseismicity data in earthquake hazard characterization.

(C) 2005 Elsevier B.V. All rights reserved.

Keywords: Paleoseismology; Seismicity; Quaternary; Geomorphology; Seismic hazard

\section{Introduction}

Paleoseismology is the study of ground effects from past earthquakes as preserved in the geologic and geomorphic record. Through the integration of geology (primarily Quaternary), seismology, archaeology, history, and tectonic information, paleoseismic research provides data and criteria for (a) quantifying the rates of ongoing tectonic activity in a region (e.g., Vittori et al., 1991; McCalpin, 1996; Michetti and Hancock, 1997; Yeats et al., 1997), (b) understanding the influence of this activity on the local landscape (e.g., Wallace, 1984; Audemard, 1999; Serva et al., 2002), and (c) constraining structural and seismological models of fault behavior and growth (e.g., Wesnousky, 1988; Cowie, 1998; Gupta et al., 1998; Wesnousky, 2000; Roberts and Michetti, 2004).

These research lines broadly summarize the main fields of investigation that can significantly benefit from paleoseismic analyses. Paleoseismology is a young and developing discipline and, under several respects, is still lacking firm methodological paradigms. However, the past decades of research have made quite clear which are the most relevant directions for paleoseismological studies in the near future. This paper describes some of the major implications of research performed for two INQUA inter-congress periods of activity in the framework of the Subcommission on Paleoseismicity (1995-2003), and provides an outline of the general scope of paleoseismic investigations necessary to develop appropriate data for seismic hazard analyses.

In addition, this paper provides an introduction to this Special Issue on "Paleoseismology, integrated study of the Quaternary geological record for earthquake deformation and faulting", arising from selected research presented during three INQUA Subcommis- sion on Paleoseismicity sponsored events in the past 5 years. ${ }^{1}$

\section{Paleoseismology: looking for paradigms}

Fault trench investigations, and in general the study of all categories of seismites (sensu Vittori et al., 1991), are aimed at determining the seismic nature of the features under observation, and the magnitude(s) and date(s) of the causative earthquake(s). A proper understanding of the local seismic and geological setting (in other words, of the seismic landscape: Serva and Slemmons, 1995; Serva et al., 1997; Michetti and Hancock, 1997), in terms of recent tectonic and climatic evolution, crustal stress environment (e.g., Mohammadioun and Serva, 2001; Scholz, 2002), style of faulting, fault slip rates, and Quaternary geomorphic-stratigraphic framework, is the crucial requirement for achieving these goals. The resulting data on location, magnitude, and recurrence of large earthquakes form the basic input to seismic hazard analyses, with the goal of characterizing the risk to the built environment from earthquakes.

The methodology and techniques for paleoseismological characterization of source parameters, however, are still evolving. Work conducted in the past decade has shown that "standards" in paleoseismology have a very short life, because this is a relatively new field of scientific investigation, and the methodologies have

\footnotetext{
${ }^{1}$ (i) XVI INQUA Congress, Durban, South Africa, August 3-10, 1999, Session and Workshop P4, "Quaternary geology, Paleoseismicity and seismic hazard assessment for critical facilities such as nuclear power plants".(ii) 31st IGC, Rio de Janeiro, Brazil, August 6 to 17,2000 , Special Symposium E-3, "Active Tectonics, Geomorphology, Paleoseismicity”.(iii) INQUA-PAGES-BRUNEL Conference, Uxbridge, West London UK, Aug. 27-Sept. 3, 2002, Session SS4a "Holocene Paleoseismicity: geological criteria for mitigating future seismic catastrophes".
} 
evolved to encompass very broad and multidisciplinary approaches for characterization of past earthquakes. The following sections describe the major issues and provide recommended approaches for paleoseismic investigations, with specific emphasis on integration of multiple data sets for robust characterization of the magnitude and recurrence of earthquakes.

Given that a fault has been identified as a potential earthquake source, the critical task for paleoseismic investigations is to estimate the magnitude, recurrence rate, and timing of paleoearthquakes. Approaches in estimating magnitudes of paleoearthquakes commonly are based on empirical relationships between rupture parameters (surface length and displacement) and magnitude (described in Wells and Coppersmith, 1994; Stirling et al., 2002). The earthquake recurrence rate is a function of the fault slip rate and earthquake magnitude, and it has a direct effect on the seismic hazard associated with the fault because average earthquake recurrence intervals tend to decrease as slip rates increase (e.g., Roberts et al., 2004). Paleoseismic data developed in recent years and in a variety of tectonic settings (e.g., Swan, 1988; Crone and Luza, 1990; McCalpin and Nishenko, 1996; Benedetti et al., 2002; Zilberman et al., 2005-this volume) clearly show that for some fault zones, temporal clustering of paleoearthquakes is more of a rule than an exception. Historical seismicity records of several regions worldwide, in fact, also indicate that sequences or clusters of earthquakes may be separated by much longer periods of quiescence (e.g., Ambraseys et al., 1994, 2002, for the Near East; Postpischl, 1985a,b, for Italy). If earthquake sequences on a given fault exhibit temporal clustering, analysis of paleoearthquake dates and slip rates will allow only qualitative evaluations of the timing of future events, unless both the short-term and long-term recurrence behavior of that fault is very well constrained. Considerable debate has ensured regarding the applicability of various types recurrence models (for a comprehensive review see, for instance, Scholz, 2002; and references herein).

Of course, even if the interpretation of paleoseismic data describing the distribution of seismicity through time requires particular prudence, this only emphasizes the need to develop better constraints on and reduce uncertainty in paleoearthquake dates, earthquake recurrence intervals, and fault slip rates. One essential strategy is to compare information from several categories of paleoseismic evidence. Off-fault evidence for past earthquakes, such as seismite layers and other soft sediment deformations (e.g., Ken-Tor et al., 2001; Marco and Agnon, 2005-this volume; Mörner, 2005-this volume), liquefaction (e.g., Talwani and Cox, 1985; Amick and Gelinas, 1991; Tuttle, 2001; Guccione, 2005-this volume), stream response to gradient changes (e.g., Russ, 1982; Schumm et al., 2000; Guccione, 2005-this volume), broken speleothems (e.g., Lemeille et al., 1999), tsunami deposits and turbidites (e.g., Clague et al., 2000; Schnellmann et al., 2002; Mörner, 2005-this volume), landslides (e.g., Bell et al., 1998; Dramis and Blumetti, 2005this volume; Rust, 2005 - this volume), and damage to man-made structures (e.g., Ellenblum et al., 1998; in this volume, see the papers by Piccardi; Silva et al.; Zilberman et al.; and reference herein) are all useful for assessing paleoearthquake dates and magnitudes, and earthquake recurrence rates, and should be consistently combined with fault trench results.

Fault trenching investigations are critical to paleoseismic analysis because they have the potential to provide a direct assessment of the amount and timing of fault movement. However, it should be noted that not always trench investigations along a fault segment are in fact able to capture all recent surface faulting events which occurred along that segment. For instance, the earthquake rupture may not occupy exactly the same trace every time. Capable faults ${ }^{2}$ might be prominent, composite tectonic structures, especially when viewed at the scale of a trench excavation site (tens to a few hundreds of meters). Typically fault zones are wider and more complex at bends of the fault trace in map view, or within stepovers. Their surface expression might be distributed over a significant fault width across strike, and often includes a set of second-order surface ruptures, such as antithetic, en-echelon, and release faults.

Strong normal faulting earthquakes from the extensional provinces of Italy and Greece, for instance, typically reactivate only some of the several Holocene fault scarps developed during the growth of the causative capable fault segment

\footnotetext{
${ }^{2}$ Capable faults are those active faults that have the potential for generating displacement at or near the ground surface (e.g., Azzaro et al., 1998; IAEA, 2002), and therefore can be directly studied through exploratory trenches.
} 
(e.g., Jackson et al., 1982; Westaway and Jackson, 1984; Stewart and Hancock, 1988, 1991; Michetti et al., 2000; Porfido et al., 2002; Morewood and Roberts, 2002; Papanikolau et al., 2005-this volume). The Irpinia-Lucania area in Italy is a very clear example of how important timing of events is in capturing a full understanding of fault behavior for hazard analysis. This area was hit by an $\mathrm{M}_{\mathrm{S}}$ 6.9, intensity X (MCS scale) earthquake on November 23, 1980, and by an intensity X earthquake on September 8, 1694 (Serva, 1981; Postpischl, 1985a,b). The reported damage, ground effects and isoseismal maps for the two earthquakes are nearly identical, which strongly suggest that they were generated by the same seismogenic source (Porfido et al., 2002). However, trench investigations along the surface ruptures that accompanied the November 23, 1980, M6.9, Irpinia-Lucania normal faulting earthquake in Italy demonstrated that surface faulting apparently did not occur at these sites during the 1694 earthquake as the penultimate event is constrained to have occurred at least 1500 to 2000 years before present (Pantosti et al., 1993a,b). Evidence for the 1694 surface rupture is therefore likely preserved along other Holocene scarps that did not break during the 1980 event (Salvi and Nardi, 1991; Porfido et al., 2002), or at other sites along the 1980 ruptures. Coseismic surface faulting was in fact quite extensive, including an over 40-km-long main rupture (Westaway and Jackson, 1984; Pantosti et al., 1993a,b), a 7-kmlong, cross-fault rupture in the Senerchia area within the footwall of the main rupture (Cinque et al., 1981), and at least two parallel, ca. 8-km-long, antithetic ruptures in the Muro Lucano area (Blumetti et al., 2003; Porfido et al., 2002).

Available paleoseismic data sets are generally insufficient to provide robust estimates of the variability in earthquake recurrence intervals or to precisely estimate fault slip rates (Grant, 2002). However, the identification of and precise dating of large magnitude paleoearthquakes provide data that can be used to assess whether seismic hazard evaluations based only on historical and instrumental seismicity adequately model the recurrence of large magnitude earthquakes. The case of the "aseismic" Pollino region in Southern Italy is emblematic in this regard (e.g., Michetti et al., 2000).
The variability or uncertainty in recurrence rates can easily be addressed in hazard analysis through the use of logic trees or Monte Carlo simulations. The more difficult issue is to adequately estimate the variability/quantify the uncertainty in recurrence intervals/slip rates. However, inclusion of uncertainty in hazard analysis is necessary to adequately evaluating the hazard, specifically to avoid significantly underestimating seismic hazard (e.g., Gürpinar, 2005-this volume).

\section{Lessons learned from the intensity scales}

It is well known that seismic events produce effects on the geological environment, especially if hypocentral depth is shallow (say, less than $20 \mathrm{~km}$ ) and magnitude is significant (say, more than 5). Most earthquake intensity scales adequately consider these effects (for a comprehensive analysis of the environmental phenomena considered in the Mercalli-Cancani-Sieberg (MCS), Modified Mercalli (MM), and Medvedev-Sponheuer-Karnik (MSK) intensity scales, see Dengler and McPherson, 1993; Serva, 1994; Esposito et al., 1997). In paleoseismology, when geologists assess the magnitude of past earthquakes, a single category of paleoseismic evidence (such as fault rupture length or surface displacement, size of liquefaction features, and amount of coseismic uplift of shorelines) is generally used. However, it is useful to check the assessed magnitude for consistency with other phenomena (mainly ground shaking effects in the epicentral area, such as quality and quantity of landslides, changes in topography, tsunamis) that are described in the intensity scales at the intensity degree coherent with the assessed magnitude and focal depth, and with the local geologicgeomorphic setting. This is one of the main rationales for the newly proposed INQUA intensity scale (Michetti et al., 2004), which is only based on ground effects. The full discussion of the INQUA scale is available in the ad hoc paper presented at the XVI INQUA Congress in Reno (Michetti et al., 2004). Here we use the INQUA scale to show that when shallow crustal (hypocentral depth in the order of 10 to $20 \mathrm{~km}$ ) seismic events with epicentral intensity $\geq$ VIII in the MM scale (which can be considered equivalent to intensity VIII or higher in the INQUA, 


\section{A MAXDISPLACEMENT (55 earthquakes)}

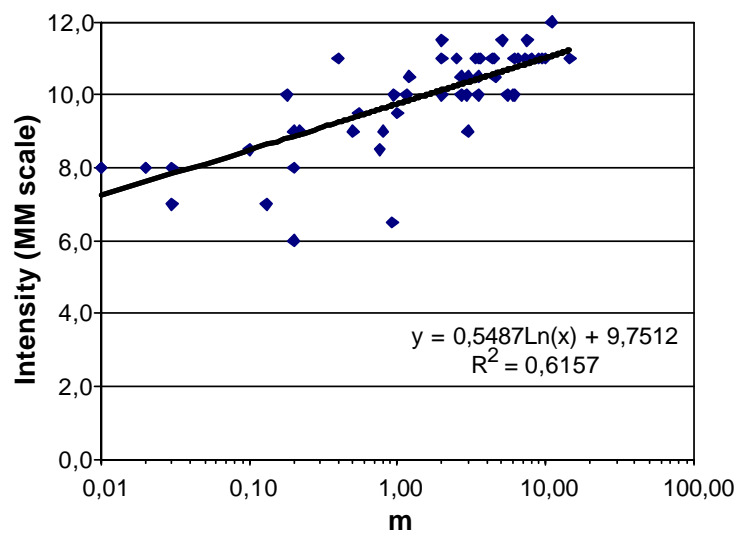

B SURLENGTH (58 earthquakes)

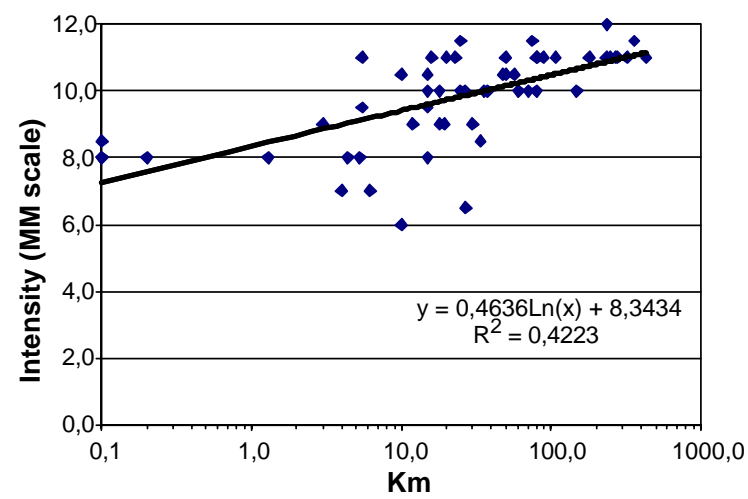

Fig. 1. Diagram showing relations between epicentral intensity and surface faulting ([A] maximum displacement, $\mathrm{MD}$; [B] surface rupture length, SRL) parameters for crustal earthquakes (hypocentral depth in the order of 10 to $20 \mathrm{~km}$ ); data from seismic events listed in Table 3 of Michetti et al. (2004); regressions of epicentral I on MD and SRL give the equations represented by the solid lines in panels (A and B), respectively.

MCS, and MSK scales) $)^{3}$ are considered, in terms of geological evidence there is no "blind" earthquake source. For strong seismic events, coseismic effects on the natural environments are so clear and widespread that their cumulative expression over a geological time interval can be recognized in the field. Obviously, confirming the seismically-triggered origin of some features is often not an easy process (e.g., Hanson et al., 1999). However, investigations to cat-

\footnotetext{
${ }^{3}$ For a detailed comparison among the scales, see Shebalin et al. (1974); Krinitsky and Chang (1988); Reiter (1991).
}

alog the extent of ground effects and their repeated occurrence over time typically enable an observer to detect the presence of a tectonic structure capable of generating large magnitude earthquakes.

A similar observation was made by Lettis et al. (1997), in that reverse earthquakes, including "blind" thrust earthquakes, were associated with recognizable deformation of surficial geologic deposits or quantifiable tectonic deformation of landscapes. A compilation of epicentral intensity values for more than 70 earthquakes accompanied by surface faulting phenomena (and mostly belonging to the same set of events studied by Wells and Coppersmith, 1994) shows a significant correlation between surface rupture length, maximum displacement and epicentral intensity (Fig. 1). It is evident that intensity VIII MM (or MCS or MSK) is the threshold at which surface faulting becomes a consistently detectable and quantifiable phenomenon. When surface faulting cannot be observed, for instance because the causative fault is located offshore or the fault does not rupture to the ground surface, a wide range of other ground effects can be investigated, as shown in Appendix A. As an example of this approach, Guccione (2005-this volume) describes the extensive use of ground surface features in the New Madrid seismic zone for identification and characterization of past earthquakes.

\section{Paleoseismology and seismic hazard assessment}

Paleoseismology in the past decades has been used for investigating a variety of earthquake characteristics such as distribution of slip along the strike (e.g., Roberts and Michetti, 2004; Papanikolau et al., 2005-this volume), deformation rates in active tectonics regions (e.g., Collier et al., 1998; Papanikolau et al., 2005-this volume); for assessing the dates of earthquakes and intra-event recurrence intervals to calculate time-dependent probabilities of earthquake occurrence (McCalpin and Nishenko, 1996; Working Group on California Earthquake Probabilities, 2003), evaluating the distribution of damage and ground effects (in order to model possible future scenarios; e.g., Mörner, 2005-this volume; Zilberman et al., 2005-this volume), site effects (e.g., Silva et al., 2005 - this volume), and testing magnitude-frequency distribution models (e.g., Wesnousky et al., 1983; 
Schwartz and Coppersmith, 1984; Wesnousky and Leffler, 1992; Roberts, 1996; Grant, 2002). However, seismic hazard assessment remains the most relevant framework for paleoseismic analyses worldwide, and is in fact the fundamental basis for most of the research listed above. In our opinion, without a solid context of seismic hazard analysis, paleoseismology might easily loose internal consistency, and become a rather academic exercise. It is therefore convenient, at this point, to review the seismotectonic background in which paleoseismic studies must be incorporated (e.g., Allen, 1975; 1986; Slemmons and dePolo, 1986; Coppersmith, 1991; Gürpinar, 2005-this volume).

As already pointed out, some of the coseismic phenomena described in the intensity scales, or their cumulative effects, are used for the recognition of past earthquakes. Fig. 2 summarizes the main steps required to produce a reliable database for seismic hazard analyses (see also IAEA, 2002; Gürpinar, 2005-this volume).

Geological-geomorphological mapping provides the basic tool for defining the stratigraphy, structural geology and tectonic history of the region. The tectonic history should be very well characterized for the more pertinent recent periods. For instance, Late Pleistocene to Holocene is generally the appropriate time-window for interplate regions, while Pliocene to Quaternary is often best for intraplate regions. Use of age dating, of any applicable methodology, is strongly recommended to assess the age and timing of deformation of stratigraphic units or geomorphic features.

For the understanding of the current tectonic regime and rates of activity, the following should be used: aerial photographs, remote sensing data (such as those derived from satellite imagery), GPS and interferometry data, strain rate measurements, mapping and analysis of Quaternary formations and/or landforms (such as terrace analysis and investigation of drainage network evolution), and pedological and sedimentological studies. Usually, it is necessary to perform detailed geomorphological-geological mapping, geophysical prospecting, or subsurface investigation to fully characterize the identified structures. Subsurface information derived from geological and geophysical investigations (such as drilling, seismic reflection and refraction, gravimetric, electric and magnetic techniques) is also useful to spatially characterize the identified structures in terms of geometry, extent, and rate of deformation. Heat flow data could also be useful.

Investigations should be done in sufficient detail such that the causes of each relevant recent (according to the pertinent time-window for the specific local tectonic environment) geological and geomorphological feature, such as linear topographic or structural features seen on photographs, remote sensing imagery or geophysical data, might be properly included in a reasonable model for the recent geological evolution of the area.

Based on the framework of information needed for seismic hazard analysis (described above), paleoseismic data are of decisive value in the following fields:

a) Identification of the relevant earthquake sources, such as capable faults (following the well-established regulatory terminology arising from the seismic hazard assessment for nuclear power plants; e.g., IAEA, 2002; Gürpinar, 2005-this volume; see also California Geological Survey, 1997; New Zealand Ministry for the Environment, 2003) or other active tectonic structures (such as deep structures within subduction zones). Recognition of effects of past earthquakes in the region, such as fault scarps (Papanikolau et al., 2005-this volume), soft-sediment deformation (Marco and Agnon, 2005-this volume) and liquefaction features (Guccione, 2005-this volume), is useful for this goal.

b) Estimation of the maximum potential earthquake for a given seismogenic structure. This is typically performed using (i) empirical relations between fossil ground effects (such as displacement per event and/or rupture length from paleoearthquake scarps studies; e.g., Papanikolau et al., 2005-this volume) and magnitude, and (ii) seismic landscape scales (as discussed below; see also Dramis and Blumetti, 2005-this volume), using the integrated evidence of recurrent coseismic effects (for instance, using slip rates for evaluating the cumulative effects of several surface faulting earthquakes) over a geological time interval.

c) Precise identification and dating of pre-historic earthquakes. For instance, trenching across youthful fault scarp/traces allows for assessment of the location of capable fault traces, and measurement of size (e.g., using the thickness of colluvial 


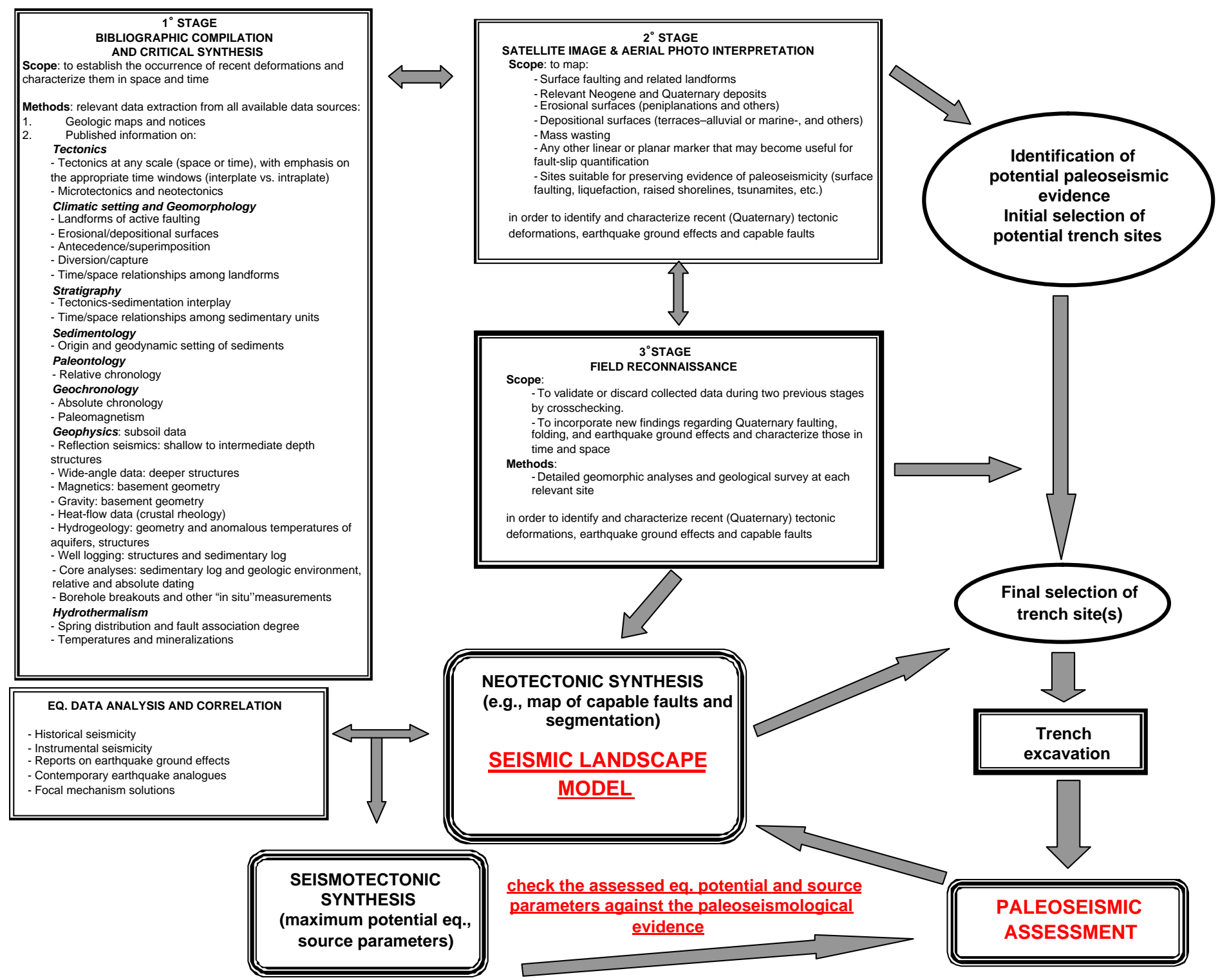

Fig. 2. Proposed flow chart methodology for the use of paleoseismology in seismic hazard assessment; adapted from Audemard (1989). For an approach specifically defined for application to nuclear facilities, see IAEA (2002) and Gürpinar (2005-this volume). 
wedge(s); e.g., McCalpin, 1996; Audemard, 2005-this volume; McCalpin, 2005-this volume; Zilberman et al., 2005-this volume) and age (when suitable sediments for dating are encountered) of past event(s).

d) Quantification of seismic source parameters from $\mathrm{a}, \mathrm{b}$, and $\mathrm{c}$, for input to probabilistic and deterministic hazards analyses.

e) Calibration or checks of probabilistic hazards analyses. The assessed seismic hazard must be in agreement with the paleoseismological evidence (e.g., Gürpinar, 2005-this volume). If an M7 earthquake is hypothesized, for instance, along a crustal normal fault, evidence for surface faulting of the appropriate dimension should be found in the field. Otherwise, the hypothesis is wrong and the entire process should be reconsidered.

From the five points listed above, there are several critical issues to be discussed in greater detail, specifically (A) the applicability of empirical relations between surface faulting and magnitude, and (B) how the concept of seismic landscape is useful in understanding seismic behavior and hazards.

\section{Empirical databases, seismic landscape, and the value of Quaternary geological evidence for understanding seismicity}

(A) The most widely used correlations between surface faulting characteristics and earthquake magnitude are the ones derived by Wells and Coppersmith (1994). Wells and Coppersmith (1994) clearly indicate that the proposed regressions (a) show large standard deviations and (b) are derived from crustal earthquakes and cannot be applied to all tectonic environments in the Earth. This is usually ignored and it is common practice in the scientific literature to just use the regression lines as "true" physical laws.

Fig. 3, modified from Mohammadioun and Serva (2001), serves to illustrate this point. It shows a comparison between data from the Apennines, the eastern flank of Mount Etna Volcano in Sicily, and the Wells and Coppersmith (1994) database. First, it is possible to note that the Apennines earthquakes are in good agreement with the worldwide data. They also show that the magnitude threshold for surface faulting

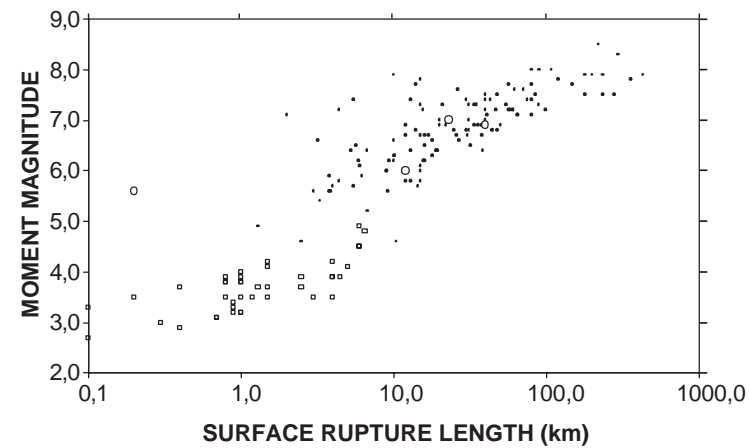

Fig. 3. Earthquake surface rupture length vs. moment magnitude (M) for earthquakes in the Central and Southern Apennines (circles), the eastern flank of Mt. Etna Volcano (squares), and data from Wells and Coppersmith (1994; dots). Adapted from Mohammadioun and Serva, 2001.

in the Apennines, and elsewhere, lies in the range of 5.5 to 6.0 . This is illustrated by the September 26, 1997, M5.7 and 6.0 Colfiorito (Vittori et al., 2000), and the September 9, 1998, M5.6 Lauria (Michetti et al., 2000; Serva et al., 2002) earthquakes. This observation further challenges the commonly accepted premise that earthquakes of magnitude 5.5 to 6.0 do not produce surface rupture. Engineers may not be very concerned about surface rupture for these smaller earthquakes because the displacements are small and are not significant for most structures. However, in countries characterized by ancient building stocks, and high vulnerability, such as in Europe, the Mediterranean region, and the Middle East, geological identification of faults capable for small offset per event might be extremely valuable for earthquake risk mitigation.

Second, and perhaps more important, data from eastern Sicily illustrate that the Wells and Coppersmith (1994) relationships, in some cases, can be also significantly inadequate to estimate magnitudes (another data set that addresses this issue is Hanks and Bakun, 2002). Along the eastern flank of the Mt. Etna volcano, a set of capable faults including the Moscarello fault (a normal fault segment located at the northern end of the well-known Malta escarpment; Azzaro et al., 2000), during modest but shallow tectonic earthquakes produces surface faulting. As shown in Fig. 3, data from this area follow an entirely different lengthmagnitude scaling, due to the peculiar local tectonic conditions. As pointed out by Mohammadioun and 
Serva (2001), the apparent difference in scaling observed in the Mt. Etna earthquakes shows that it is worthwhile to conduct further investigation to see if other geographic regions/tectonic settings are different from the worldwide data sets. In any case, this effort will provide regional relationships that are more representative of the local crustal stress environment (for instance, see Ambraseys and Jackson, 1998; Ambraseys et al., 2002; Pavlides et al., 2000, for the Eastern Mediterranean region; and Stirling et al., 2002, for New Zealand), and more appropriate for earthquake hazard characterization.

(B) It is obviously always best to build up a specific database that will allow a reliable estimate of magnitude for the events identified by paleoseismological techniques. In this line, the concept of "seismic landscape", defined as the cumulative geomorphological and stratigraphic effect of the signs left on the environment of an area by its past earthquakes over a geologically recent time interval, provides a suitable framework for the study of seismic behavior and hazards. It is important to emphasize that the term seismic landscape refers first of all to a conceptual landscape (Serva et al., 1997; Michetti and Hancock, 1997). It is quite evident that the magnitude given to a seismic event identified, for instance, by trenching analyses should be consistent with the geomorphology and stratigraphy of the area (refer to the OcaAncón fault case in Audemard, 2005-this volume). In landscapes where surface displacements and deformation by young faulting exceeds the destructive or concealing action of erosion and sedimentation, this comparison is a relatively straightforward task. Many surface effects of an earthquake, including faulting, liquefaction, landslides, coastline uplift, subsidence, repeated over a tectonic cycle, generate a specific local topographic and stratigraphic expression, which to be interpreted properly must be distinguished from non-tectonic effects. The paper by Guccione (2005-this volume), among others, clearly demonstrates that this is true even if sedimentation rates are much greater than fault slip rates. In a geomorphic environment dominated by fluvial deposition and erosion, such as the Mississippi Valley in the Reelfoot Rift zone (epicentral area of the 1811-12 New Madrid seismic sequence), the cumulative Holocene evidence for paleoseismicity, that is, the local seismic landscape, is indicated by, and must be investigated through, the analysis of extensive liquefaction features, short-lived folds and scarps, and stream/river drainage anomalies.

More in general, assuming that recurring earthquakes are not random in time, space and magnitude, as clearly indicated by the Quaternary geological evidence (Allen, 1975; Slemmons and dePolo, 1986; Michetti and Hancock, 1997), it is a reasonable
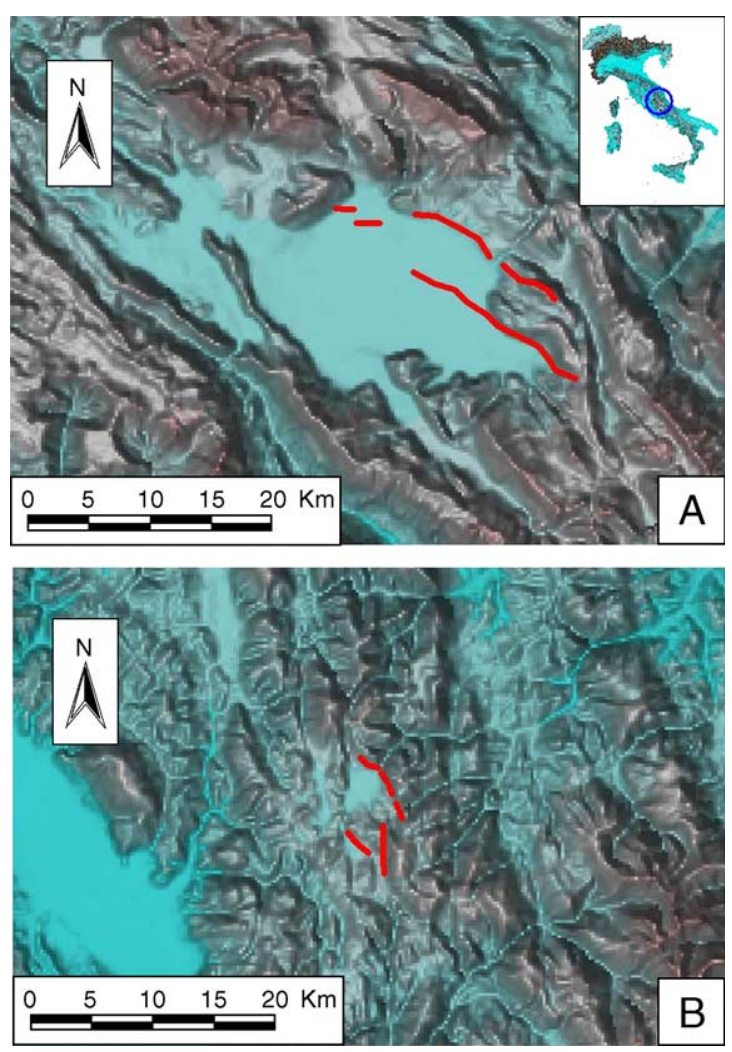

Fig. 4. Shaded relief map showing comparison between topography and contemporary earthquake surface faulting (in red) for two intermountain basins in Central Italy, (A) the Fucino basin, affected by the January 13, 1915, $\mathrm{M}_{\mathrm{S}} 7.0$ earthquake (Michetti et al., 1996), and (B) the Colfiorito basin, affected by the September 26, 1997, M 5.6 and 6.0 earthquakes (Vittori et al., 2000). The differences in the geomorphology of the two basins are consistent with the repeated occurrence of similar earthquakes of different magnitude and rupture length over the Quaternary, so that it is possible, within the extensional setting of the Apennines, to define (A) as a M7-type seismic landscape, and (B) as a M6-type seismic landscape. For a full discussion, see Serva et al. (2002), from which this figure is adapted. (For interpretation of the references to colour in this figure legend, the reader is referred to the web version of this article.) 
working hypothesis that earthquakes should influence the evolution of an area in such a way as to enable an observer to recognize features in the local geologic landscape that are diagnostic of general magnitudes of earthquakes (e.g., M 6, M 7, M 8). The main controlling factors for this "seismic landscape" are (a) the geodynamic setting in which the seismic source is located, including style of faulting, rate of tectonic activity, and the thickness and rheology of the seismogenic layer, (b) the local climatic, geomorphic, sedimentary, and anthropic environment and the Quaternary history, because the cumulative effect at or near the surface also depends on rates of erosion and deposition. Within a region, a seismogenic structure capable of, say, M 7 earthquakes appears to form a characteristic seismic landscape that is different from the seismic landscape formed by a structure capable only of M 6 earthquakes. In most cases, and especially where tectonic deformation dominates over erosional/ depositional processes and controls the morphogenesis of the region, these different seismic landscapes are associated with a distinctive geomorphic expression. A specific example in Italy is the relative size of the Fucino and Colfiorito basins, which are bounded by active normal faults that have ruptured in earthquakes of $\sim$ M 7 and $\sim$ M 6 , respectively (Fig. 4).

However, taking into account that stratigraphy is the sedimentary record of buried, fossil environments, we emphasize again that the term seismic landscape is used here to indicate the full range of geological effects resulting from significant earthquakes. In coupling geomorphology and recent stratigraphy, it is possible to define a scale of seismic landscapes, conceptually equivalent to a magnitude (or intensity) scale, that provides input values for the seismic hazard assessment in terms of location, geometry, seismic potential and rates of activity of the relevant earthquake sources. To reach this goal, the following methodological approach is recommended. First, the location, geometry and seismic potential (magnitude and rate of occurrence of the "characteristic" earthquake) of possible relevant earthquake sources in the region should be analyzed following the approach recommended in Fig. 2. Second, according to the assessed seismic potential, the expected assemblage of paleoseismic features should be defined. Third, the resulting hypotheses should be tested against the paleoseismic evidence in the field, near each outlined

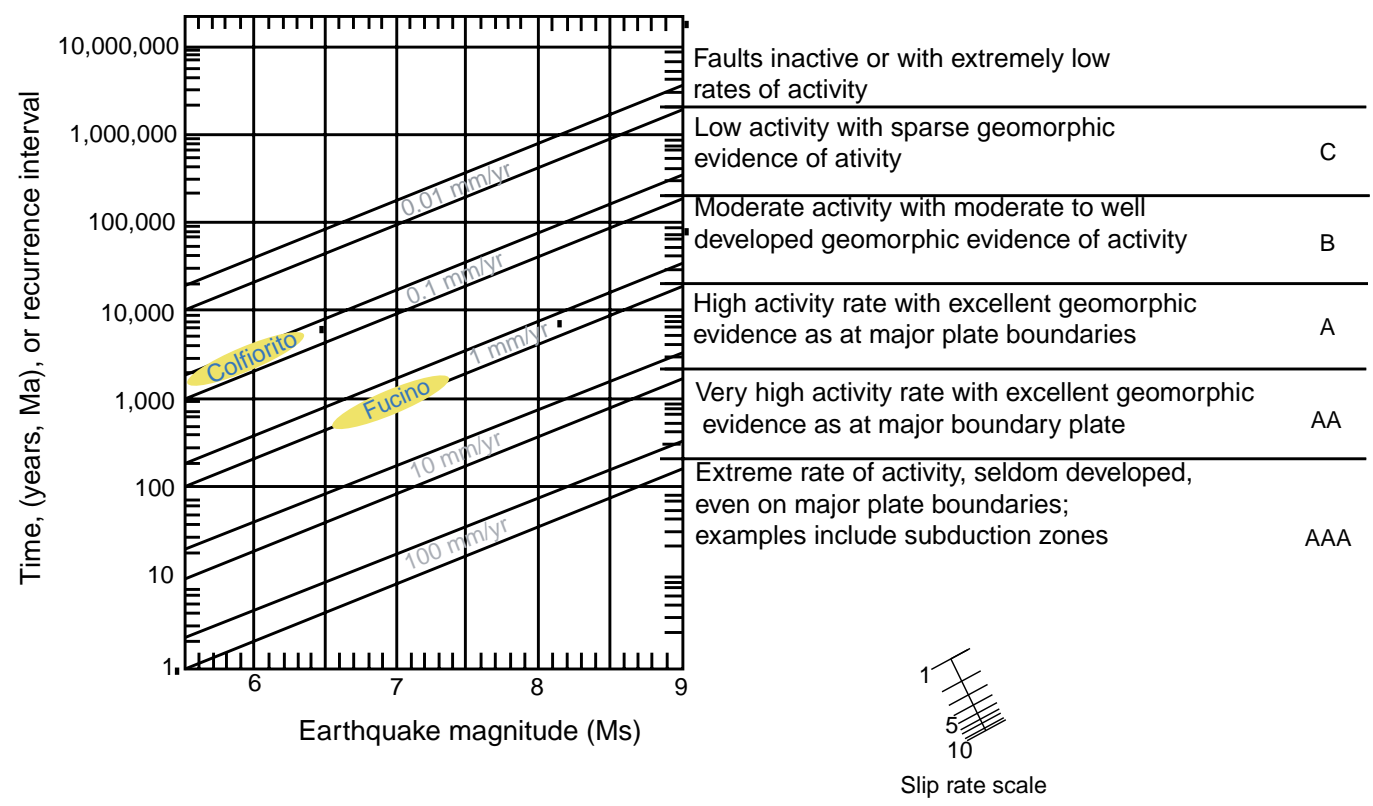

Fig. 5. Diagram of earthquake magnitude-frequency vs. the geomorphic evidence of capable faults in areas where tectonic rates exceed climatic rates of landscape modeling. Following Serva et al. (2002), data from the Fucino and Colfiorito basin in Fig. 4 have been included; it is quite evident that the two basins are representative of two different seismic landscapes, characterized by M7 and M6 earthquakes, respectively. Modified from Slemmons and dePolo (1986). 
source, and also in the subsurface (e.g., using exploratory trenching). If the paleoseismological evidence does not fit the assessed earthquake magnitude and recurrence, the adopted seismic landscape is wrong, and the described methodological steps should be reconsidered, until a proper calibration of the source parameters is obtained. This approach guarantees that the assessed magnitude and recurrence are consistent with the geological, geomorphic and paleoseismic evidence around the causative earthquake source(s).

As noted above, Fig. 4 represents, in a way, the concept expressed above. It is clear that the shape of the two Apennines intermountain basins shows the cumulative effects of repeated earthquakes of a "characteristic" magnitude and recurrence over a geological time interval, in this case basically the Quaternary period (Serva et al., 2002, and reference herein).

Slemmons and dePolo (1986) described a similar concept using typical relations between slip rates and geomorphic expression of capable faults from worldwide observations (Fig. 5, adapted from Serva et al., 2002, to include the examples of the two basins shown in Fig. 4). The concept of seismic landscape is a logical extension of the Slemmons and dePolo (1986) approach, suitably developed to take full advantage from the Quaternary geological evidence of all types of coseismic ground effects.

\section{Paleoseismology, integrated study of the Quaternary geological record for earthquake deformation and faulting: a Special Issue}

This Special Issue presents selected state-of-theart paleoseismic studies from the perspective of several years (1995 to present) of activity of the INQUA Subcommission on Paleoseismicity. The contributed papers in this issue have been ordered following first a methodological criterion, and then according to the pertinent geographical and Quaternary tectonic setting. The first paper by Gürpinar gives the engineering needs of a "user" of paleoseismic results, which provides a context for paleoseismological studies in the seismic hazard assessment of critical facilities, such as dams, chemical/petrochemical facilities and nuclear power plants. The paper by Audemard, based on the experience of several decades of research in Venezuela, gives, arguably for the first time in the international scientific literature, the basic technical guidelines on how to plan and conduct a paleoseismic investigation using exploratory trenches. Ota et al. (2005-this volume) illustrate the extraordinary advance of paleoseismic investigations that occurred in Taiwan following the recent $\mathrm{M}_{\mathrm{W}}$ 7.6 1999 Chi-Chi earthquake. Zilberman et al., and Marco and Agnon, introduce different methodological approaches and results from paleoseismic studies along the Dead Sea transform fault. From a different tectonic setting, Piccardi describes paleoseismic research along another major strike-slip structure, the right-lateral Gargano fault system in the Apulia foreland, Italy. Similar to the studies in Israel, his study takes advantage of historical and archaeological evidence. The evidence for archaeoseismology is also the main focus of Silva et al. in analyzing the possible environmental and site effects recorded at the Roman town of Baelo Claudia, in southern Spain.

Moving to a normal faulting environment, Papanikolau et al. use paleoseismic and fault slip rate data to describe and quantify ongoing crustal extension in the Central Apennines of Italy. Dramis and Blumetti present a wide review of the relations between earthquakes and geomorphology in the Mediterranean region, especially focusing on surface deformation and displacement from combined tectonic and gravitational processes.

Landscapes characterized by gravitational deformation and earthquake faulting are also the focus of Rust, who describes the paleoseismological features of the Big Bend region of the San Andreas fault in the Transverse Ranges of California. Moving eastward from the strike-slip deformation in California to the Basin and Range extensional province, McCalpin describes Quaternary deformation in the Rio Grande Rift of New Mexico.

Guccione describes the paleoseismic investigations in the intraplate setting of the Mississippi Valley region of the central U.S., and Mörner describes the remarkable Latest Pleistocene to Holocene paleoseismic catalogue of Sweden, providing a comparison of the two stable cratonic regions.

In summary, this volume of work shows how Quaternary, and frequently late Quaternary, geological evidence provides critical data for interpreting and extending the study of the seismicity of a region 
beyond the historical record, resulting in a more robust characterization of the seismic hazards to the built environment.

\section{Acknowledgments}

We are deeply indebted to all the referees that assisted in the editorial process for the Special Issue, and in particular with Susan Olig and Donald
Wells who provided extremely positive and useful revisions for this paper. Leonello Serva contributed significantly to the science of this introduction and strongly encouraged the development of this Special Issue. Discussions with John Clague, Burt Slemmons, Eutizio Vittori, Karl Mueller, and Steve Wesnousky greatly helped in focusing the issues debated in this paper. The kind assistance of Giancanio Sileo in the final editorial process was also much appreciated.

\section{Appendix A}

Comparison between the INQUA scale and the Modified Mercalli scale (Wood and Neumann, 1931) for the grades VIII and above (from Michetti et al., 2004); in the INQUA scale, text in italics refers to those effects directly usable to define an intensity degree (e.g., jumping stones, soil cracking, surface faulting).

\begin{tabular}{ll}
\hline Intensity & Modified Mercalli scale of 1931 \\
\hline VIII & Fright general_alarm approaches panic. Disturbed persons \\
& driving motor cars. Trees shaken strongly_branches, trunks, \\
& broken off, especially palm trees. Ejected sand and mud in \\
& small amounts. Changes: temporary, permanent; in flow of \\
& springs and wells; dry wells renewed flow; in temperature of \\
& spring and well waters. Damage slight in structures (brick) \\
& built especially to withstand earthquakes. Considerable in \\
& ordinary substantial buildings, partial collapse: racked, \\
& tumbled down, wooden houses in some cases; threw out \\
& panel walls in frame structures, broke off decayed piling. \\
& Fall of walls. Cracked, broke, solid stone walls seriously. \\
& Wet ground to some extent, also ground on steep slopes. \\
& Twisting, fall, of chimneys, columns, monuments, also factory \\
& stack, towers. Moved conspicuously, overturned, very heavy \\
& furniture.
\end{tabular}

\section{INQUA Scale}

\section{Considerable effects on the environment}

Primary effects observed rarely. Ground ruptures (surface faulting) may develop, up to several hundred meters long, with offsets generally smaller than $5 \mathrm{~cm}$, particularly for very shallow focus earthquakes, such as volcano-tectonic events. Tectonic subsidence or uplift of the ground surface with maximum values on the order of a few centimeters may occur. Fractures up to $25-50 \mathrm{~cm}$ wide are commonly observed in loose alluvial deposits and/or saturated soils; in rare cases fractures up to $1 \mathrm{~cm}$ can be observed in competent dry rocks. Decimetric cracks common in paved (asphalt or stone) roads, as well as small pressure undulations.

Springs can change, generally temporarily, their flow rate and/ or elevation of outcrop. Some small springs may even run dry. Variations in water level are observed in wells.

Water temperature often changes in springs and/or wells. Water in lakes and rivers frequently becomes muddy.

Small to moderate $\left(10^{3}-10^{5} \mathrm{~m}^{3}\right)$ landslides widespread in prone areas; they rarely can occur also on gentle slopes; where equilibrium is unstable (steep slopes of loose/saturated soils; rock falls on steep gorges, coastal cliffs) their size is sometimes large $\left(10^{5}-10^{6} \mathrm{~m}^{3}\right)$. Landslides can occasionally dam narrow valleys causing temporary or even permanent lakes. Ruptures, slides and falls affect riverbanks and artificial embankments and excavations (e.g., road cuts, quarries) in loose sediment or weathered/fractured rock. The affected area is usually less than $100 \mathrm{~km}^{2}$.

Liquefaction may be frequent in the epicentral area, depending on local conditions; sand boils up to ca. $1 \mathrm{~m}$ in diameter; apparent water fountains in still waters; localised lateral spreading and settlements (subsidence up to ca. $30 \mathrm{~cm}$ ), with fissuring parallel to waterfront areas (riverbanks, lakes, canals, seashores). 
Appendix A (continued)

Intensity Modified Mercalli scale of 1931

VIII
Panic general. Cracked ground conspicuously. Damage considerable in (masonry) structure build especially to withstand earthquakes: threw out of plumb some wood-frame houses built especially to withstand earthquakes; great in substantial (masonry) buildings, some collapse in large part; or wholly shifted frame buildings off foundations, racked frames; serious to reservoirs; underground pipes sometimes broken.

\section{INQUA Scale}

Karst vaults may collapse, forming sinkholes.

Frequent occurrence of landslides under the sea level in coastal areas.

Significant waves develop in still and running waters.

Trees shake vigorously; some branches or rarely even tree-trunks in very unstable equilibrium may break and fall. In dry areas, dust clouds may rise from the ground in the epicentral area.

\section{Natural effects leave significant and permanent traces in} the environment.

Primary effects observed commonly. Ground ruptures (surface faulting) develop, up to a few $\mathrm{km}$ long, with offsets generally smaller than 10-20 cm. Tectonic subsidence or uplift of the ground surface with maximum values in the order of a few decimeters may occur.

Fractures up to 50-100 cm wide are commonly observed in loose alluvial deposits and/or saturated soils; in competent rocks they can reach up to $10 \mathrm{~cm}$. Significant cracks common in paved (asphalt or stone) roads, as well as small pressure undulations.

Springs can change their flow rate and/or elevation of outcrop to a considerable extent. Some small springs may even run dry. Variations in water level are observed in wells.

Water temperature often changes in springs and/or wells. Water in lakes and rivers frequently becomes muddy.

Landsliding widespread in prone areas, also on gentle slopes; where equilibrium is unstable (steep slopes of loose / saturated soils; rock falls on steep gorges, coastal cliffs) their size is frequently large $\left(10^{5} \mathrm{~m}^{3}\right)$, sometimes very large $\left(10^{6} \mathrm{~m}^{3}\right)$. Landslides can dam narrow valleys causing temporary or even permanent lakes. Riverbanks, artificial embankments and excavations (e.g., road cuts, quarries) frequently collapse. The affected area is usually less than $1000 \mathrm{~km}^{2}$.

Liquefaction and water upsurge are frequent; sand boils up to $3 \mathrm{~m}$ in diameter; apparent water fountains in still waters; frequent lateral spreading and settlements (subsidence of more than $\mathrm{ca} .30 \mathrm{~cm}$ ), with fissuring parallel to waterfront areas (riverbanks, lakes, canals, seashores).

Karst vaults of relevant size collapse, forming sinkholes. Frequent large landslides under the sea level in coastal areas. Large waves develop in still and running waters. Small tsunamis may reach the coastal areas with tidal waves up to $50-100 \mathrm{~cm}$ high.

Trees shake vigorously; branches or even tree-trunks in unstable equilibrium frequently break and fall.

In dry areas dust clouds may rise from the ground.

In the epicentral area, small stones may jump out of the ground, leaving typical imprints in soft soil. 
Appendix A (continued)

\begin{tabular}{ll}
\hline Intensity & Modified Mercalli scale of 1931 \\
\hline $\mathrm{X}$ & Cracked ground, especially when loose and wet, up to widths \\
& of several inches; fissures up to a yard in width ran parallel to \\
& canal and stream banks. Landslides considerable from \\
& riverbanks and steep coasts. Shifted sand and mud horizontally \\
& on beaches and flat land. Changed level of water in wells. \\
& Threw water on banks of canals, lakes, rivers, etc. Damage \\
& serious to dams, dikes, embankments. Severe to well-built \\
& wooden structures and bridges, some destroyed. Developed \\
& dangerous cracks in excellent brick walls. Destroyed most \\
& masonry and frame structures, also their foundations. Bent \\
& railroad rails slightly. Tore apart, or crushed endwise, pipe \\
& lines buried in earth. Open cracks and broad wavy folds in \\
& cement pavements and asphalt road surfaces.
\end{tabular}

INQUA Scale

Environmental effects become dominant.

Primary ruptures become leading. Ground ruptures (surface faulting) can extend for several tens of $\mathrm{km}$, with offsets reaching 50-100 cm and more (up to ca. 1-2 $\mathrm{m}$ in case of reverse faulting and 3-4 $m$ for normal faulting). Gravity grabens and elongated depressions develop; for very shallow focus earthquakes, such as volcano-tectonic events, rupture lengths might be much lower. Tectonic subsidence or uplift of the ground surface with maximum values in the order of few meters may occur. Large landslides and rock-falls $\left(>10^{5}-10^{6} \mathrm{~m}^{3}\right)$ are frequent, practically regardless to equilibrium state of the slopes, causing temporary or permanent barrier lakes. Riverbanks, artificial embankments, and sides of excavations typically collapse. Levees and earth dams may even incur serious damage. The affected area is usually up to $5000 \mathrm{~km}^{2}$.

Many springs significantly change their flow rate and/or elevation of outcrop. Some may run dry or disappear, generally temporarily. Variations in water level are observed in wells. Water temperature often changes in springs and/or wells. Water in lakes and rivers frequently becomes muddy.

Open ground cracks up to more than $1 \mathrm{~m}$ wide are frequent, mainly in loose alluvial deposits and/or saturated soils; in competent rocks opening reach several decimeters. Wide cracks develop in paved (asphalt or stone) roads, as well as pressure undulations.

Liquefaction, with water upsurge and soil compaction, may change the aspect of wide zones; sand volcanoes even more than $6 \mathrm{~m}$ in diameter; vertical subsidence even $>1 \mathrm{~m}$; large and long fissures due to lateral spreading are common.

Large karst vaults collapse, forming great sinkholes.

Frequent large landslides under the sea level in coastal areas. Large waves develop in still and running waters, and crash violently into the shores. Running (rivers, canals) and still (lakes) waters may overflow from their beds. Tsunamis reach the coastal areas, with tidal waves up to a few meters high. Trees shake vigorously; branches or even tree-trunks very frequently break and fall, if already in unstable equilibrium. In dry areas, dust clouds may rise from the ground.

Stones, even if well anchored in the soil, may jump out of the ground, leaving typical imprints in soft soil.

XI Disturbances in ground many and widespread, varying with ground material. Broad fissures, earth slumps, and land slips in soft, wet ground. Ejected water in large amounts charged with sand and mud. Caused sea-waves ("tidal" waves) of significant magnitude. Damage severe to wood-frame structures, especially near shock centers. Great to dams, dikes,

embankments, often for long distances. Few, if any (masonry), structures remained standing. Destroyed large well-built bridges by the wrecking of supporting piers, or pillars. Affected yielding wooden bridges less. Bent railroad rails greatly, and thrust them endwise. Put pipe lines buried in earthy completely out of service.

Environmental effects become essential for intensity assessment. Primary surface faulting can extend for several tens of $\mathrm{km}$ up to more than $100 \mathrm{~km}$, accompanied by offsets reaching several meters. Gravity graben, elongated depressions and pressure ridges develop. Drainage lines can be seriously offset. Tectonic subsidence or uplift of the ground surface with maximum values in the order of numerous meters may occur.

Large landslides and rock-falls $\left(>10^{5}-10^{6} \mathrm{~m} 3\right)$ are frequent, practically regardless to equilibrium state of the slopes, causing many temporary or permanent barrier lakes. Riverbanks, artificial embankments, and sides of excavations typically collapse. Levees and earth dams incur serious damage. Significant landslides can occur at 200-300 km distance from the epicenter. Primary and secondary environmental effects can be observed over territory as large as $10000 \mathrm{~km}^{2}$. 
Appendix A (continued)

Intensity Modified Mercalli scale of 1931

\section{INQUA Scale}

Damage total - practically all works of construction damaged greatly or destroyed. Disturbances in ground great and varied, numerous shearing cracks. Landslides, falls of rock of significant character, slumping of riverbanks, etc. numerous and extensive. Wrenched loose, tore off, large rock masses. Fault slips in firm rock, with notable horizontal and vertical offset displacements. Water channels, surface and underground, disturbed and modified greatly. Dammed lakes, produced waterfalls, deflected rivers, etc. Waves seen on ground surfaces (actually seen, probably, in some cases). Distorted lines of sight and level. Threw objects upward into the air.
Many springs significantly change their flow rate and/or elevation of outcrop. Frequently, they may run dry or disappear altogether. Variations in water level are observed in wells. Water temperature often changes in springs and/or wells. Water in lakes and rivers frequently becomes muddy.

Open ground cracks up to several meters wide are very frequent, mainly in loose alluvial deposits and/or saturated soils. In competent rocks they can reach $1 \mathrm{~m}$. Very wide cracks develop in paved (asphalt or stone) roads, as well as large pressure undulations.

Liquefaction changes the aspect of extensive zones of lowland, determining vertical subsidence possibly exceeding several meters, numerous large sand volcanoes, and severe lateral spreading features.

Very large karst vaults collapse, forming sinkholes.

Frequent large landslides under the sea level in coastal areas. Large waves develop in still and running water, and crash violently into the shores. Running (rivers, canals) and still (lakes) waters may overflow from their beds. Tsunamis reach the coastal areas with tidal waves up to many meters high. Trees shake vigorously; many tree branches break and several whole trees are uprooted and fall.

In dry areas dust clouds may arise from the ground.

Stones and small boulders, even if well anchored in the soil, may jump out of the ground leaving typical imprints in soft soil.

Environmental effects are now the only tool enabling intensity to be assessed.

Primary surface faulting can extend for several hundreds of $\mathrm{km}$ up to $1000 \mathrm{~km}$, accompanied by offsets reaching several tens of meters. Gravity graben, elongated depressions and pressure ridges develop. Drainage lines can be seriously offset. Landscape and geomorphological changes induced by primary effects can attain extraordinary extent and size (typical examples are the uplift or subsidence of coastlines by several meters, appearance or disappearance from sight of significant landscape elements, rivers changing course, origination of waterfalls, formation or disappearance of lakes).

Large landslides and rock-falls $\left(>10^{5}-10^{6} \mathrm{~m}^{3}\right)$ are frequent, practically regardless to equilibrium state of the slopes, causing many temporary or permanent barrier lakes. Riverbanks, artificial embankments, and sides of excavations typically collapse. Levees and earth dams incur serious damage. Significant landslides can occur at more than 200-300 km distance from the epicenter. Primary and secondary environmental effects can be observed over territory larger than $50000 \mathrm{~km}^{2}$.

Many springs significantly change their flow rate and/or elevation of outcrop. Frequently, they may run dry or disappear altogether. Variations in water level are observed in wells. Water temperature often changes in springs and/or wells. Water in lakes and rivers frequently becomes muddy. 
Appendix A (continued)

\begin{tabular}{ll}
\hline Intensity Modified Mercalli scale of 1931 & INQUA Scale \\
\hline XII & $\begin{array}{l}\text { Ground open cracks are very frequent, up to } 1 \mathrm{~m} \text { or wider in } \\
\text { the bedrock, up to more than } 10 \mathrm{~m} \text { wide in loose alluvial } \\
\text { deposits and/or saturated soils. These may extend up to several } \\
\text { kilometers in length. }\end{array}$ \\
Liquefaction occurs over large areas and changes the \\
morphology of extensive flat zones, determining vertical \\
subsidence exceeding several meters, widespread large sand \\
volcanoes, and extensive severe lateral spreading features.
\end{tabular}

\section{References}

Allen, C.R., 1975. Geologic criteria for evaluating seismicity. Geological Society of America Bulletin 86, 1041-1056.

Allen, C.R., 1986. Seismological and paleoseismological techniques of research in active tectonics. In: Wallace, R.E., (Panel Chairman). Active Tectonics, National Academy Press, Washington, pp. $148-154$.

Ambraseys, N.N., Jackson, J.A., 1998. Faulting associated with historical and recent earthquakes in the Eastern Mediterranean region. Geophysical Journal International 133, 390-406.

Ambraseys, N.N., Melville, C.P., Adams, R.D., 1994. The Seismicity of Egypt, Arabia and the Red Sea. Cambridge University Press, p. 181.

Ambraseys, N.N., Jackson, J.A., Melville, C.P., 2002. Historical seismicity and tectonics: the case of the Eastern Mediterranean and the Middle East. IASPEI. International Handbook of Earthquake and Engineering Seismology 81A, 747-763.

Amick, D., Gelinas, R., 1991. The search for evidence of large prehistoric earthquakes along the Atlantic seaboard. Science $251,655-658$.

Audemard, F.A., 1989. Néotectonique du Languedoc Mediterranéen: examen critique et synthèse des données existantes. D.E.A. Memoir, Université Montpellier II (U.S.T.L.), 60pp+26 tabl6s+ synthesis map.

Audemard, F.A., 1999. Morpho-structural expression of active thrust fault systems in the humid tropical foothills of Colombia and Venezuela. In: Frisch, W. (Ed.), Proc. Fourth Int. Conf. Geomorphology, Bologna 1997, Z. Geomorph., N.F., vol. 118, pp. 1-18.
Audemard, F.A., 2005 - this volume. Paleoseismology in Venezuela: objectives, methods, applications, limitations and perspectives. Tectonophysics 408, 297-61. doi:10.1016/j.tecto.2005.05.034.

Azzaro, R., Ferreli, L., Michetti, A.M., Serva, L., Vittori, E., 1998. Environmental hazard of capable faults: the case of the Pernicana fault (Mt. Etna, Sicily). Natural Hazards 18, 1-16.

Azzaro, R., Bella, D., Ferreli, L., Michetti, A.M., Santagati, F., Serva, L., Vittori, E., 2000. First study of fault trench stratigraphy at Mt. Etna volcano, Southern Italy: understanding Holocene surface faulting along the Moscarello fault. Journal of Geodynamics 29, 187-210.

Benedetti, L., Finkel, R., Papanastassiou, D., King, G.C.P., Armijo, R., Ryerson, F., Farber, D., Flerit, F., 2002. Post-glacial slip history of the Sparta fault (Greece) determined by ${ }^{36} \mathrm{Cl}$ cosmogenic dating: evidence for non-periodic earthquakes. Geophysical Research Letters 29. doi:810.1029/2001GL014510.

Bell, John W., Brune, J.N., Liu, Tanzhuo, Zreda, Marek, Yount, James C., 1998. Dating precariously balanced rocks in seismically active parts of California and Nevada. Geology 26 (6), 495-498.

Blumetti, A.M., Esposito, E., Ferreli, L., Michetti, A.M., Porfido, S., Serva, L., Vittori, E., 2003. New data and reinterpretation on the November 23, 1980, M 6.9 Irpinia-Lucania earthquake (Southern Apennines) coseismic surface effects. In: Dramis, F., Farabollini, P., Molin, P. (Eds.), International Workshop "Large-Scale Vertical Movements and Related Gravitational Processes", Studi Geologici Camerti, Numero Speciale 2002, pp. $19-27$.

California Geological Survey, 1997. Fault-rupture Hazard Zones in California: Special Publication 42, 38 p., with supplements 1, 2, 
and 3 in 1999 and 2003, ftp://ftp.consrv.ca.gov/pub/dmg/pubs/ $\mathrm{sp} / \mathrm{Sp} 42$.pdf.

Cinque, A., Lambiase, S., Sgrosso, I., 1981. Su due faglie nell'alta valle del Sele legate al terremoto del 23.11.1980. Rendiconti della Società Geologica Italiana 4, 127-129.

Clague, J.J., Bobrowsky, P.T., Hutchinson, I., 2000. A review of geological records of large tsunamis at Vancouver Island, British Columbia. Quaternary Science Reviews 19, 849-863.

Collier, R., Pantosti, D., D'Addezio, G., De Martini, P.M., Sakellariou, D., 1998. Paleoseismicity of the 1981 Corinth earthquake fault: seismic contribution to extensional strain in central Greece and implications for seismic hazard. Journal of Geophysical Research 103 (B12), 30001-30020.

Coppersmith, K.J., 1991. Seismic source characterization for engineering seismic hazard analysis. Proceedings of the Fourth International Seismic Zonation Conference, vol. 1. Earthquake Engineering Research Institute, Stanford, California, pp. $1-60$.

Cowie, P.A., 1998. A healing-reloading feedback control on the growth rate of seismogenic faults. Journal of Structural Geology 20, $1075-1087$.

Crone, A.J., Luza, K.V., 1990. Style and timing of Holocene surface faulting on the Meers fault, southwestern Oklahoma. Geological Society of America Bulletin 102 (1), 1-17.

Dengler, L., McPherson, R., 1993. The 17 August 1991 Honeydew earthquake North Coast California: a case for revising the Modified Mercalli scale in sparsely populated areas. Bulletin of the Seismological Society of America 83, 1081-1094.

Dramis, F., Blumetti, A.M., 2005-this volume. Some considerations concerning seismic geomorphology and paleoseismology. Tectonophysics 408, 177-191. doi:10.1016/j.tecto.2005.05.032.

Ellenblum, R., Marco, S., Agnon, A., Rockwell, T., Boas, A., 1998. Crusader castle torn apart by earthquake at dawn, 20 May 1202. Geology 26, 303-306.

Esposito, E., Porfido, S., Mastrolorenzo, G., Nikonov, A.A., Serva, L., 1997. Brief review and preliminary proposal for the use of ground effects in the macroseismic intensity assessment. In: Hong, Ye (Ed.), Proceedings 30th International Geological Congress, Beijing, China, 4-14 August 1996, vol. 5. VSP, Utrecht, The Netherlands, pp. 233-243.

Grant, L.B., 2002. Paleoseismology. In: Lee, W.H.K., Kanamori, H., Jennings, P.C., Kisslinger, C. (Eds.), International Handbook of Earthquake and Engineering Seismology, vol. 81A. IASPEI, Elsevier, pp. 475-490.

Guccione, M.J., 2005-this volume. Late Pleistocene and Holocene paleoseismology of an intraplate seismic zone in a large alluvial valley, the new Madrid seismic zone, Central USA. Tectonophysics 408, 237-264. doi:10.1016/j.tecto.2005.05.046.

Gupta, S., Cowie, P.A., Dawers, N.H., Underhill, J.R.U., 1998. A mechanism to explain rift-basin subsidence and stratigraphic patterns through fault array evolution. Geology 26, 595-598.

Gürpinar, A., 2005-this volume. The importance of paleoseismology in seismic hazard studies for critical facilities. Tectonophysics 408, 23-28. doi:10.1016/j.tecto.2005.05.042.

Hanks, T.C., Bakun, W.H., 2002. A bilinear source-scaling model for $\mathrm{M}-\log \mathrm{A}$ observations of continental earthquakes. Bulletin of the Seismological Society of America 92, 1841-1846.
Hanson, K.L., Kelson, K.I., Angell, M.A., Lettis, W.R. (Eds.), 1999. Techniques for identifying fault and determining their origins. NRC-sponsored research: Division of Engineering Technology, Office of Nuclear Regulatory Research, U.S. Nuclear Regulatory Commission, Washington, D.C., USA, NUREG/CR-5503.

IAEA, 2002. Evaluation of Seismic Hazards for Nuclear Power Plants. IAEA Safety Standard Series No. NS-G-3.3, 31 p., Vienna, 2002.

Jackson, J.A., Gagnepain, J., Houseman, G., King, G.C.P., Papadimitriou, P., Soufleris, C., Virieux, J., 1982. Seismicity, normal faulting, and the geomorphological development of the Gulf of Corinth (Greece): the Corinth earthquakes of February and March 1981. Earth and Planetary Science Letters 57, 377-397.

Ken-Tor, R., Agnon, A., Enzel, Y., Marco, S., Negendank, J.F.W., Stein, M., 2001. High resolution geological record of historic earthquakes in the Dead Sea basin. Journal of Geophysical Research 106 (B2), 2221-2234.

Krinitsky, E.L., Chang, F.K., 1988. Intensity-related earthquake ground motions. Bulletin of the Association of Engineering Geologists 25, 425-435.

Lemeille, F., Cushing, M., Carbon, D., Grellet, B., Bitterli, Th., Flehoc, Ch., Innocent, Ch., 1999. Co-seismic ruptures and deformations recorded by speleothemes in the epicentral zone of the Basle earthquake. Geodinamica Acta 12 (3-4), 179-191.

Lettis, W.R., Wells, D.L., Baldwin, J.N., 1997. Empirical observations regarding reverse earthquakes, blind thrust faults, and quaternary deformation: are blind thrust faults truly blind? Bulletin of the Seismological Society of America 87 (5), 1171-1198.

Marco, S., Agnon, A., 2005-this volume. High-resolution stratigraphy reveals repeated earthquake faulting revealed by high resolution stratigraphy. Tectonophysics 408, 101-112. doi:10.1016/ j.tecto.2005.05.036.

McCalpin, J.P. (Ed.), 1996. Paleoseismology. Academic Press, London (583 pp.).

McCalpin, J.P., 2005- this volume. Late Quaternary activity of the Pajarito fault, Rio Grande rift of northern New Mexico, USA. Tectonophysics 408, 213-236. doi:10.1016/j.tecto.2005.05.038.

McCalpin, J.P., Nishenko, S.P., 1996. Holocene paleoseismicity, temporal clustering, and probabilities of future large $(M>7)$ earthquakes on the Wasatch fault zone, Utah. Journal of Geophysical Research, [Solid Earth] 101 (B3), 6233-6253.

Michetti, A.M., Hancock, P.L., 1997. Paleoseismology: understanding past earthquakes using quaternary geology. Journal of Geodynamics 24 (1-4), 3-10.

Michetti, A.M., Brunamonte, F., Serva, L., Vittori, E., 1996. Trench investigations of the 1915 Fucino earthquake fault scarps (Abruzzo, Central Italy): geological evidence of large historical events. Journal of Geophysical Research 101 (B3), 5921-5936.

Michetti, A.M., Ferreli, L., Esposito, E., Porfido, S., Blumetti, A.M., Vittori, E., Serva, L., Roberts, G.P., 2000. Ground effects during the 9 September 1998, $\mathrm{Mw}=5.6$, Lauria earthquake and the seismic potential of the "aseismic" Pollino region in Southern Italy. Seismological Research Letters 71 (1), 31-46.

Michetti, A.M., Esposito, E., Mohammadioun, B., Mohammadioun, J., Gürpinar, A., Porfido, S., Rogozhin, E., Serva, L., Tatevos- 
sian, R., Vittori, E., Audemard, F., Comerci, B., Marco, S., McCalpin, J., Mörner, N.A., 2004. The INQUA scale: an innovative approach for assessing earthquake intensities based on seismically-induced ground effects in the environment. In: Vittori, E., Comerci, V. (Eds.), Special Paper, Memorie Descrittive della Carta Geologica d'Italia, vol. LXVII (120 pp.).

Mohammadioun, B., Serva, L., 2001. Stress drop, slip type, earthquake magnitude - and seismic hazard. Bulletin of the Seismological Society of America 91, 694-707.

Morewood, N.C., Roberts, G.P., 2002. Surface observations of active normal fault propagation: implications for growth. Journal of the Geological Society (London) 159, 263-272.

Mörner, N.A., 2005-this volume. An interpretation and catalogue of paleoseismology in Sweden. Tectonophysics 408, 265-307. doi:10.1016/j.tecto.2005.05.039.

New Zealand Ministry for the Environment, 2003. Planning for Development of Land on or Close to Active Faults: An interim guideline to assist resource management planners in New Zealand: http:// www.mfe.govt.nz/publications/rma/active-faults-jul03/.

Ota, Y., Chen, Y.G., Chen, W.S., 2005-this volume. Review of paleoseismological and active fault studies in Taiwan in the light of the Chichi earthquake of September 21, 1999. Tectonophysics 408, 63-77. doi:10.1016/j.tecto.2005.05.040.

Pantosti, D., D’Addezio, G., Cinti, F.R., 1993a. Paleoseismological evidence of repeated large earthquakes along the 1980 Irpinia earthquake fault. Annali di Geofisica 36 (1), 321-330.

Pantosti, D., Schwartz, D.P., Valensise, G., 1993b. Paleoseismology along the 1980 Irpinia earthquake fault and implications for earthquake recurrence in the southern Apennines. Journal of Geophysical Research 98, 6561-6577.

Papanikolau, I.D., Roberts, G.P., Michetti, A.M., 2005-this volume. Fault scarps and deformation rates in Lazio-Abruzzo, Central Italy: comparison between geological fault slip-rate and GPS data. Tectonophysics 408, 147-176. doi:10.1016/ j.tecto.2005.05.043.

Pavlides, S., Caputo, R., Chatzipetros, A., 2000. Empirical relationships among earthquake magnitude, surface ruptures and maximum displacement in the broader Aegean region. Proc. 3rd Intern. Geolog. Congr. Eastern Mediteranean, Nikosia-Cyprus, Sept. 1998, pp. 159-168.

Piccardi, L., 2005-this volume. Paleoseismic evidence of legendary earthquakes: the apparition of Archangel Michael at Monte Sant' Angelo (Italy). Tectonophysics 408, 113-128. doi:10.1016/ j.tecto.2005.05.041.

Porfido, S., Esposito, E., Vittori, E., Tranfaglia, G., Michetti, A.M., Blumetti, A.M., Ferreli, L., Guerrieri, L., Serva, L., 2002. Areal distribution of ground effects induced by strong earthquakes in the southern Apennines (Italy). Surveys in Geophysics 23, $529-562$.

Postpischl, D. (Ed.), 1985a. Atlas of Isoseismal Maps of Italian Earthquakes, CNR-PFG, Quaderni della Ricerca Scientifica, vol. 114 (2A). Graficoop Bologna, Bologna (164 pp.).

Postpischl, D. (Ed.), 1985b. Catalogo dei terremoti italiani dall'anno 1000 al 1980, CNR-PFG, Quaderni della Ricerca Scientifica, vol. 114 (2B). Graficoop Bologna, Bologna (243 pp.).

Reiter, L., 1991. Earthquake Hazard Analysis. Columbia University Press (254 pp.).
Roberts, G.P., 1996. Noncharacteristic normal faulting surface ruptures from the Gulf of Corinth, Greece. Journal of Geophysical Research 101, 25255-25267.

Roberts, G.P., Michetti, A.M., 2004. Spatial and temporal variations in growth rates along active normal fault systems: an example from the Lazio-Abruzzo Apennines, central Italy. Journal of Structural Geology 26 (2004), 339-376.

Roberts, G.P., Cowie, P., Papanikolaou, I., Michetti, A.M., 2004. Fault scaling relationships, deformation rates and seismic hazards: an example from the Lazio-Abruzzo Apennines, Central Italy. Journal of Structural Geology 26, 377-398.

Russ, D.P., 1982. Style and significance of surface deformation in the vicinity of New Madrid, Missouri. In: Russ, D.P., Carone, A.J. (Eds.), The New Madrid, Missouri, Earthquake RegionGeological, Seismological and Geotechnical studies, U.S. Geological Survey Professional Paper 1336-H, pp. 95-114.

Rust, D., 2005 - this volume. Paleoseismology in steep terrain: the big bend of the San Andreas Fault, Transverse Ranges, California. Tectonophysics 408, 193-212. doi:10.1016/j.tecto.2005.05.037.

Salvi, S., Nardi, A., 1991. Contribution of Landsat synthetic stereopair to morphotectonic analysis in the Irpinia area (Southern Italy). Il Quaternario 4, 107-120.

Schnellmann, M., Anselmetti, F.S., Giardini, D., McKenzie, J.A., Ward, S.N., 2002. Prehistoric earthquake history revealed by lacustrine slump deposits. Geology 30 (12), 1131-1134.

Scholz, C.H., 2002. The Mechanics of Earthquakes and Faulting, 2nd ed. Cambridge Univ. Press (471 pp.).

Schumm, S.A., Dumont, J.F., Holbrook, J.M., 2000. Active Tectonics and Alluvial Rivers. Cambridge University Press, New York (276 pp.).

Schwartz, P.D., Coppersmith, K.J., 1984. Fault behaviour and characteristic earthquakes: examples from the Wasatch and San Andreas Fault. Journal of Geophysical Research 89, 5681-5698.

Serva, L., 1981. Il terremoto del 1694 in Irpinia e Basilicata. Volume speciale della Commissione ENEA-ENEL: Contributo alla caratterizzazione della sismicità del territorio Italiano. CNR, Convegno annuale Geodinamica, Udine, pp. 183-208.

Serva, L., 1994. Ground effects in the intensity scales. Terra Nova 6, 414-416.

Serva, L., Slemmons, D.B., 1995. Perspective in paleoseismology. A.E.G. Special Publication, vol. 6. Peanut Butter Publishing, Seattle, Washington (138 pp.).

Serva, L., Vittori, E., Ferreli, L., Michetti, A.M., 1997. Geology and seismic hazard. In: Grellet, B., Mohammadioun, B., Hays, W. (Eds.), Proceedings of the Second France-United States Workshop on Earthquake Hazard Assessment in Intraplate Regions: Central and Eastern United States and Western Europe, October 16, 1995, Nice, France, 20-24, Ouest Editions, Nantes, France.

Serva, L., Blumetti, A.M., Guerrieri, L., Michetti, A.M., 2002. The Apennine intermountain basins: the result of repeated strong earthquakes over a geological time interval. Bollettino della Società Geologica Italiana. Volume Speciale 1 (2001), 939-946.

Shebalin, N.V., Karnik, V., Hadzievski, D., 1974. Catalogue of earthquakes of the Balkan region: I. UNDP-UNESCO Survey of the seismicity of the Balkan region, Skopje (600 pp.). 
Silva, P.G., Borja, F., Zazo, C., Goy, J.L., Bardajš, T., De Luque, L., Lario, J., Dabrio, C.J., 2005-this volume. Archeoseismic record at the ancient Roman City of Baelo Claudia (Cádiz, South Spain). Tectonophysics 408, 129-146. doi:10.1016/ j.tecto.2005.05.031

Slemmons, D.B., dePolo, C.M., 1986. Evaluation of active faulting and associated hazard. In: Wallace, R.E., (Panel Chairman). Active Tectonics, National Academy Press, Washington D.C., pp. 45-62.

Stewart, I.S., Hancock, P.L., 1988. Normal fault zone evolution and fault scarp degradation in the Aegean region. Basin Research 1, $139-154$.

Stewart, I.S., Hancock, P.L., 1991. Scales of structural heterogeneity within neotectonic normal fault zones in the Aegean region. Journal of Structural Geology 13, 191-204.

Stirling, M., Rhoades, D., Berryman, K., 2002. Comparison of earthquake scaling relations derived from data of the instrumental and pre-instrumental era. Bulletin of the Seismological Society of America 92 (2), 812-830.

Swan, F.H., 1988. Temporal clustering of paleoseismic events on the Oued Fodda fault, Algeria. Geology 16, 1092-1095.

Talwani, P., Cox, J., 1985. Paleoseismic evidence for recurrence of earthquakes near Charleston, South Carolina. Science 229, 379-381.

Tuttle, M.P., 2001. The use of liquefaction features in paleoseismology: lessons learned in the New Madrid seismic zone, central United States. Journal of Seismology 5 (3), 361-380.

Vittori, E., Sylos-Labini, S., Serva, L., 1991. Paleoseismology: review of the state of the art. Tectonophysics 193, 9-32.

Vittori, E., Deiana, G., Esposito, E., Ferreli, L., Marchegiani, L., Mastrolorenzo, G., Michetti, A.M., Porfido, S., Serva, L., Simonelli, A.L., Tondi, E., 2000. Ground effects and surface faulting in the September-October 1997 Umbria-Marche (Central Italy) seismic sequence. Journal of Geodynamics 29 (3-5), 535-564.

Wallace, R.E., 1984. Fault scarps formed during the earthquake of October 2, 1915, in Pleasant Valley, Nevada, and some tectonic implication. Faulting Related to the 1915 Earthquakes in Pleasant Valley, Nevada, U.S. Geological Survey Prof. Paper, vol. 1274-A, pp. 1-33.

Wells, D.L., Coppersmith, K.J., 1994. New empirical relationships among magnitude, rupture length, rupture width, rupture area, and surface displacement. Bulletin of the Seismological Society of America 84, 974-1002.

Wesnousky, S.G., 1988. Seismological and structural evolution of strike-slip faults. Nature 335, 340-343.

Wesnousky, S.G., 2000. The role of neotectonics in the study of fault mechanics and seismic hazard. Active Fault Research for the Millenium, Proceedings of the Hokudan International Symposium and School on Active Faulting, pp. 545-552.

Wesnousky, S.G., Leffler, L., 1992. The repeat time of the 1811-12 new Madrid earthquakes: a geological perspective. Bulletin of the Seismological Society of America 82, 1756-1786.

Wesnousky, S.G., Scholz, C.H., Shimazaki, K., 1983. Earthquake frequency distribution and the mechanics of faulting. Journal of Geophysical Research 88, 9331-9340.

Westaway, R., Jackson, J.A., 1984. Surface faulting in the southern Italian Campania-Basilicata earthquake of 23 November 1980. Nature 312, 436-438.

Wood, H.O., Neumann, F., 1931. Modified Mercalli intensity scale of 1931. Bulletin of the Seismological Society of America 21, $277-283$.

Working Group on California Earthquake Probabilities (WG02), 2003. Earthquake probabilities in the San Francisco Bay region: 2002-2031: U.S. Geological Survey Open-File Report 03-214. URL: http://geopubs.wr.usgs.gov/open-file/of03-214/.

Yeats, R.S., Sieh, K., Allen, C.R., 1997. The Geology of Earthquakes. Oxford University Press, New York (568 pp.).

Zilberman, E., Amit, R., Porat, N., Enzel, Y., Avner, U., 2005-this volume. Surface ruptures induced by the devastating $1068 \mathrm{Ad}$ earthquake in the southern Arava Valley, Dead Sea rift, Israel. Tectonophysics 408, 79-99. doi:10.1016/j.tecto.2005.05.030. 